\title{
ANALISIS PEMAHAMAN KONSEPTUAL MAHASISWA PENDIDIKAN MATEMATIKA UINSU MEDAN TERHADAP MATERI GRUP PADA MATA KULIAH STRUKTUR ALJABAR
}

\section{ANALYSIS OF CONCEPTUAL UNDERSTANDING OF MATH EDUCATION STUDENT OF UINSU MEDAN ON GROUP MATERIAL IN ALGEBRAIC STRUCTURES COURSE}

\author{
Abdullah Afdhol Richsan ${ }^{a}$, Dilla Safera Siregar ${ }^{b}$, Siti Maysarah $^{c}$ \\ aProgram Studi Pendidikan Matematika FITK UIN SU \\ J1. Williem Iskandar Pasar V Medan Estate, afdhol1502@ gmail.com \\ bProgram Studi Pendidikan Matematika FITK UIN SU \\ J1. Williem Iskandar Pasar V Medan Estate, dillasafera123@gmail.com \\ 'Program Studi Pendidikan Matematika FITK UIN SU \\ Jl. Williem Iskandar Pasar V Medan Estate, sitimaysarah@uinsu.ac.id
}

\begin{abstract}
ABSTRAK
Penelitian ini bertujuan untuk mendeskripsikan pemahaman konseptual mahasiswa pendidikan matematika terhadap materi grup pada mata kuliah struktur aljabar. Penelitian ini dilakukan pada mahasiswa Universitas Islam Negeri Sumatera Utara Medan. Subjek yang digunakan dalam penelitian ini diambil dari mahasiswa pendidikan matematika semester 5 yang telah mempelajari materi grup. Metode yang digunakan dalam penelitian ini adalah deskriptif. Pengumpulan data dilakukan dengan teknik tes dan wawancara dengan mempertimbangkan indikator pemahaman konseptual. Hasil penelitian menunjukkan bahwa hasil rata-rata indikator pemahaman konseptual mahasiswa terhadap materi grup berada pada tingkat menengah. Kemudian dinyatakan bahwa mahasiswa dengan kemampuan matematis yang tinggi akan memiliki pemahaman konseptual yang baik, sedangkan mahasiswa dengan kemampuan matematis yang rendah tidak memiliki pemahaman konseptual yang baik.
\end{abstract}

Kata Kunci : pemahaman konsep, konsep grup, kemampuan matematis

\section{ABSTRACT}

This study aims to describe the conceptual understanding of mathematics education students on group material in the algebraic structure. This research was conducted on students of the State Islamic University of North Sumatra, Medan. Subjects used in this study were taken from 5th semester mathematics education students who studied group material. Method used in this research is descriptive. Data was collected using test and interview techniques by considering indicators of conceptual understanding. The result showed that the average result of the indicator of students' conceptual understanding of the group material were at the intermediate level. Then it was stated that students with high mathematical abilities would have a good conceptual understanding, while students with low mathematical abilities didn't have a good conceptual understanding.

Keywords : understanding of concept, group concept, mathematical ability 


\section{Pendahuluan}

Matematika adalah pelajaran yang dipelajari dari tingkat dasar sampai tingkat perguruan tinggi, matematika merupakan ilmu pengetahuan yang dibutuhkan semua bidang. Dalam kehidupan sehari-hari matematika diperlukan untuk berhitung dan menyimpulkan sesuatu (Hayu et al., 2019)

Aljabar merupakan salah satu cabang dari ilmu matematika. Pengembangan dari aljabar ini adalah struktur aljabar. Matakuliah struktur aljabar grup adalah salah satu matakuliah yang wajib ditempuh oleh mahasiswa program sarjana jurusan Pendidikan matematika di Universitas Islam Negeri (UIN) Sumatera Utara pada semester 5. Menurut Fitria (2014) Matakuliah struktur aljabar adalah salah satu matakuliah yang sangat penting dalam bidang matematika karena struktur aljabar adalah salah satu syarat mempelajari struktur-struktur himpunan yang lebih kompleks.

Fitria (2014) juga berpendapat bahwa struktur aljabar grup merupakan salah satu matakuliah yang mempunyai karakter yang abstrak dan logika di sini sangat diperlukan dalam struktur aljabar serta sistematis dari semua definisi dan teorema sangat kental untuk dipelajari dan difahami, sehingga dapat disimpulkan bahwasanya struktur aljabar merupakan salah satu matakuliah yang dapat melatih dan mengasah kemampuan berpikir serta dapat menciptakan penalaran dan logika berpikir abstrak.

Kreativitas matematika sangat diperlukan dalam mengembangkan pemahaman konseptual matematika dan juga untuk mengembangkan bakat matematika (Maysarah, 2017).

Matematika memiliki kaitan yang erat dengan operasi dan konsep. Dengan mempelajari matematika, mahasiswa diharapkan dapat mengerti, mengusai dan memahami tentang konsep matematika. Mahasiswa diharuskan untuk tidak hanya sekedar tahu dan hafal mengenai konsep yang terdapat dalam matematika, tetapi juga harus mengerti dan memahami konsep-konsep tersebut, kemudian dapat menghubungkan keterkaitannya antara suatu konsep dengan konsep yang lain (Listiawati, 2015).

Melalui perkuliahan struktur aljabar dengan mempelajari dan memahami struktur aljabar, mahasiswa diharapkan mampu untuk membuat kesimpulan dari berbagai sistem matematika yang sudah dikenal sebelumnya, sehingga mahasiswa dapat memperoleh pemahaman yang lebih mendalam tentang konsep-konsep dari struktur aljabar (Fadillah \& Jamilah, 2016).

Konsep merupakan ide abstrak yang memungkinkan untuk memilah 
ataupun mengelompokkan objek ke dalam sebuah contoh ataupun non contoh (Ruseffendi, 2006). Menurut Hamalik (2000) konsep adalah sebuah kategori stimulus yang memiliki ciri umum. Konsep matematika akan disusun secara urut kemudian konsep sebelumnya dapat digunakan untuk mempelajari konsep yang lebih lanjut. Misalkan materi tentang grup akan diajarkan terlebih dahulu dari pada materi tentang grup abelian. Pemahaman terhadap konsep materi prasyarat ini sangat penting bagi mahasiswa untuk menguasai dan memahami konsep pada materi selanjutnya.

Menurut Faizah (2019), untuk dapat membuktikan dan menyelesaikan suatu permasalahan ataupun problem dalam struktur aljabar grup, terutama pada materi tentang grup, mahasiswa diharuskan untuk memahami setiap konsep yang ada dalam materi grup. Suatu konsep matematika akan dikuasai oleh mahasiswa jika mahasiswa tersebut cermat dalam memahami keterkaitan suatu konsep dengan konsep sebelumnya yang sudah dipelajari, hal ini dapat dikatakan sebagai pemahaman konseptual (Rubowo et al., 2017).

Mahasiswa akan dikatakan memahami sebuah konsep, jika mahasiswa dapat mendefenisikan, dan mengidentifikasi serta memberikan contoh dan bukan contoh dalam persoalan, kemudian mampu mengembangkan kemampuan koneksi matematika antar berbagai macam ide, dan memahami bagaimana sebuah konsep saling terkait satu dengan yang lainnya sehingga dapat membangun pemahaman yang menyeluruh dan dapat menggunakan konsep matematika dalam konteks di luar dari matematika tersebut (Nila, 2008).

Silver (dalam Haji, 2014), berpendapat bahwa strategi pencapaian suatu konsep akan dimulai dari menyampaikan sebuah konsep lalu memberikan contoh dan bukan contoh. Amir (2015) berpendapat bahwa seorang akan memiliki kemampuan dalam memahami konsep jika mampu memberikan contoh dan bukan contoh atau mengilustrasikan sautu konsep untuk memperjelas.

Dalam memahami sebuah konsep, kemampuan pemecahan masalah matematis sangat diperlukan, karena kemampuan pemecahan masalah termasuk sebuah kemampuan yang menempati tujuan umum dan tujuan utama dalam pembelajaran matematika (Darma et al., 2016). Pemecahan masalah adalah salah satu aspek yang penting dalam melakukan pembelajaran, dengan pemecahan masalah yang baik maka akan membantu dalam mengasah berpikir secara kritis (Ambarwati, 2016). 
Menurut Darminto (2013), Kemampuan pemecahan masalah termasuk ke dalam kemampuan matematis tinggi dan berhubungan dengan kehidupan sehari-hari. Untuk memecahkan masalah matematis maka perlunya memahami masalah, kemudian merencanakan penyelesaian, dan melaksanakan rencana tersebut, kemudian kembali memeriksa proses dan hasilnya (Amalia \& Widodo, 2018).

Berdasarkan penelitian yang dilakukan oleh Fitria (2014) tentang miskonsepsi mahasiswa dalam menentukan grup pada struktur aljabar manyatakan bahwa dari 34 orang mahasiswa terdapat $48,12 \%$ mahasiswa mengalami miskonsepsi sedangkan sisanya $26,07 \%$ tahu konsep dan $25,81 \%$ tidak tahu konsep. Berdasarkan hasil wawancara yang dilakukan yaitu penyebab terjadinya miskonsepsi karena karakter dari konsep grup yang bersifat abstrak.

\section{Kemudian Faizah} melakukan penelitian untuk menganalisis pemahaman konseptual mahasiswa calon guru matematika di Universitas PGRI Adi Buana Surabaya tentang grup ditinjau dari kemampuan matematika. Hasil dari penelitian tersebut mendapatkan tiga kesimpulan, dimana mahasiswa dengan kemampuan matematika tinggi mencapai indikator pemahaman konseptual dengan sempurna, sedangkan mahasiswa dengan kemampuan matematika sedang mencapai indikator pemahaman konseptual yang kurang sempurna, dan mahasiswa dengan kemampuan matematika yang rendah tidak dapat memahami konsep dengan baik.

Pemahaman konseptual sangatlah penting sebagai tolak ukur bagi mahasiswa dalam proses pembelajaran terutama pembelajaran grup pada matakuliah struktur aljabar grup. Pemahaman konseptual mengenai grup akan menjadi dasar bagi mahasiswa untuk melanjutkan ke materi dan permasalahan yang lebih kompleks pada mata kuliah struktur aljabar. Oleh karena itu, pemahaman konseptual pada materi grup harus ditanamkan kepada mahasiswa pada awal perkuliahan struktur aljabar grup agar mahasiswa dapat memahami dan mempelajari teori yang lebih kompleks.

Berdasarkan latar belakang yang telah diuraikan, maka dapat dinyatakan bahwa tujuan dari penelitian ini adalah untuk mendeskripsikan pemahaman konseptual mahasiswa pendidikan matematika UIN SU Medan terhadap materi grup pada mata kuliah struktur aljabar grup. Adapun perbedaan antara penelitian ini dengan penelitian yang dilakukan oleh Faizah (2019) terletak pada subjek penelitian, dimana subjek dalam penelitian yang dilakukan oleh 
Faizah (2019) diambil dari mahasiswa di Universitas PGRI Adi Buana Surabaya dengan subjek yang telah ditentukan oleh peneliti yaitu mahasiswa dengan kemampuan matematis tinggi, sedang, dan rendah. Sedangkan dalam penelitian ini subjek diambil secara acak dari mahasiswa pendidikan matematika UIN SU Medan tanpa membandingkan tingkat kemampuan matematis dari mahasiswa tersebut.

\section{Metode Penelitian}

Metode yang digunakan dalam penelitian ini adalah metode penelitian deskriptif. Subjek penelitian ini dipilih acak dari mahasiswa pendidikan matematika Universitas Islam Negeri Sumatera Utara Medan. Pemilihan subjek penelitian didasari dengan pertimbangan ; (1) subjek diambil dari mahasiswa semester 5 pendidikan matematika UIN SU Medan, (2) mahasiswa yang dipilih adalah mahasiswa pendidikan matematika yang telah mempelajari atau membahas materi tentang grup pada perkuliahan struktur aljabar grup, (3) memilih 4 orang mahasiswa secara acak tanpa menilai kemampuan matematis mahasiswa tersebut. Instrumen dalam penelitian ini terbagi menjadi instrumen utama dan pendukung, dimana instrumen utama dalam penelitian ini adalah peneliti sendiri kemudian instumen lainnya, yaitu soal tes yang digunakan untuk memperoleh data pemahaman konseptual mahasiswa pendidikan matematika terhadap materi grup dan wawancara dilakukan untuk mendapatkan keabsahan dari data hasil kerja mahasiswa pada tes yang telah dilakukan.

Pengumpulan data dilakukan dengan teknik tes dan teknik wawancara. Subjek penelitian akan diberikan soal tes yang telah divalidasi dan wawancara dilakukan dengan mempertimbangkan indikator pemahaman konseptual. Menurut Darminto (2009) Pemahaman konsep aljabar adalah salah satu kemahiran aljabar yang dapat tercapai melalui penunjukkan keterkaitan antar konsep secara tepat dalam pemecahan masalah. Indikator pemahaman konseptual yang harus dimiliki antara lain:

1) menyatakan atau menjelaskan ulang sebuah konsep,

2) meng-klasifikasikan sifat-sifat tertentu,

3) memberi contoh,

4) merepresentasikan konsep,

5) menggunakan konsep untuk menyelesaikan masalah

Sehingga indikator pemahaman konseptual dalam penelitian ini dapat dilihat pada tabel 1 . 
Table 1. Indikator Pemahaman Konseptual

\begin{tabular}{|c|c|c|}
\hline No & Komponen & Indikator \\
\hline 1 & $\begin{array}{lr}\text { Menyatakan } & \text { atau } \\
\text { menjelaskan } & \text { ulang } \\
\text { konsep grup } & \end{array}$ & $\begin{array}{l}\text { Menjelaskan defenisi } \\
\text { grup } \\
\text { Menjelaskan } \\
\text { perbedaan antara } \\
\text { grup, semi grup, dan } \\
\text { Monoid } \\
\text { Menjelaskan defenisi } \\
\text { dari grup abelian }\end{array}$ \\
\hline 2 & $\begin{array}{l}\text { Mengklasifikasikan } \\
\text { sifat-sifat grup }\end{array}$ & $\begin{array}{l}\text { Menjelaskan sifat- } \\
\text { sifat grup dan } \\
\text { membuktikan sebuah } \\
\text { grup }\end{array}$ \\
\hline 3 & Memberikan contoh & $\begin{array}{l}\text { Memberikan contoh } \\
\text { suatu grup dan bukan } \\
\text { grup }\end{array}$ \\
\hline 4 & $\begin{array}{l}\text { Menggunakan konsep } \\
\text { untuk menyelesaikan } \\
\text { masalah }\end{array}$ & $\begin{array}{l}\text { Membuktikan dan } \\
\text { menjelaskan sebuah } \\
\text { himpunan adalah } \\
\text { grup dan merupakan } \\
\text { abelian }\end{array}$ \\
\hline
\end{tabular}

Dari hasil tes dan wawancara yang dilakukan terhadap subjek, dilakukan analisis data dengan menggunakan indikator pemahaman konseptual untuk mengetahui gambaran pemahaman konseptual subjek penelitian terhadap materi grup. Kemudian data yang telah diperoleh diuji kembali keabsahannya dengan triangulasi sehingga diperoleh data yang valid.

\section{Hasil dan Pembahasan}

Dalam penelitian ini, peneliti melakukan pengambilan data pada 4 orang mahasiswa semester V yaitu A, B, C, dan D. Peneliti meminta mahasiswa tersebut untuk mengerjakan soal yang telah diberikan. Kemudian peneliti melakukan wawancara untuk memperkuat hasil tes.

Dari penelitian yang telah dilakukan, diperoleh data berdasarkan kemampuan mahasiswa yang berbeda dalam mengerjakan soal tes tertulis dan tes secara wawancara sebagai berikut. Hasil tes yang diperoleh dapat dilihat pada gambar berikut ini :

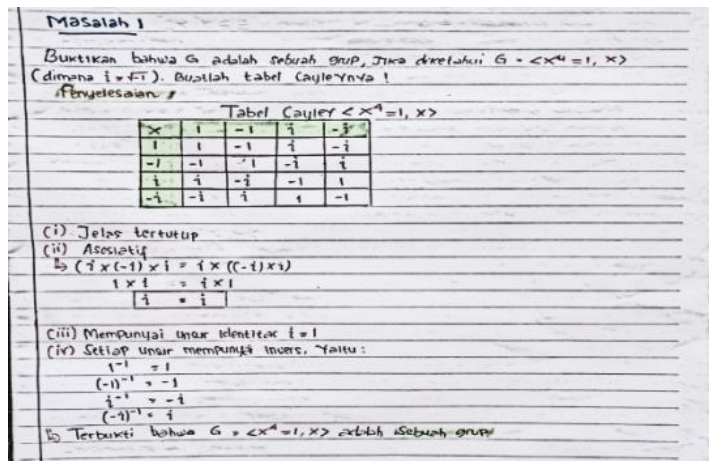

Gambar 1. Lembar Jawaban 1 A

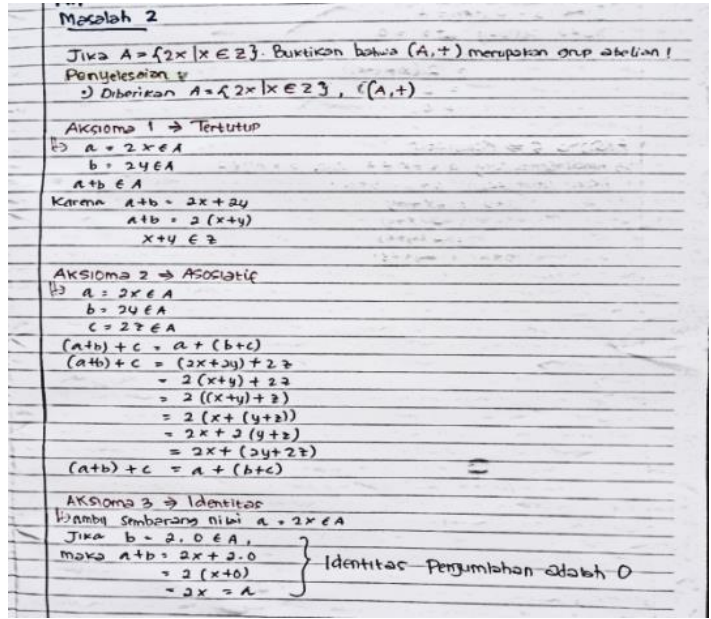

Gambar 2. Lembar Jawaban 2 A

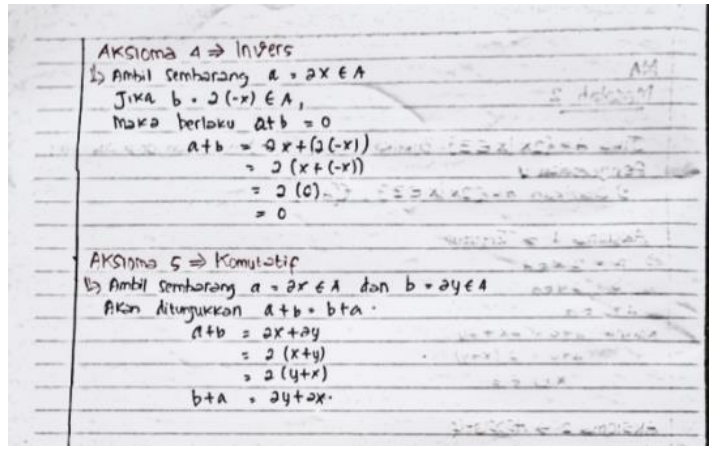

Gambar 3. Lembar Jawaban 3 A 


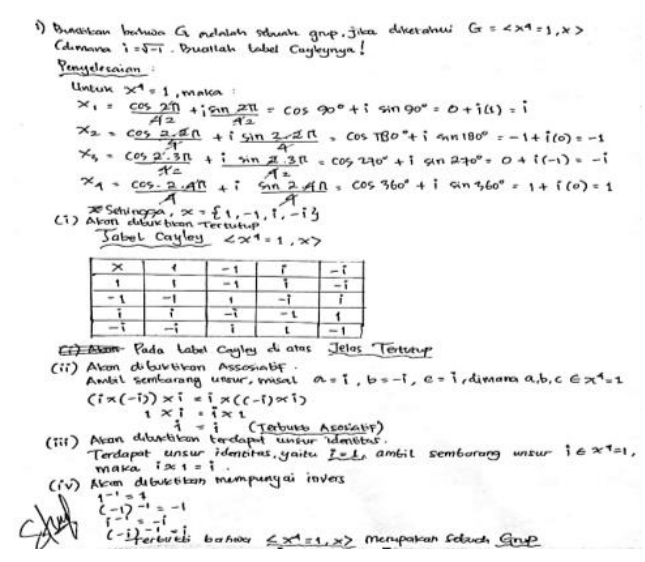

Gambar 4. Lembar Jawaban 1 B

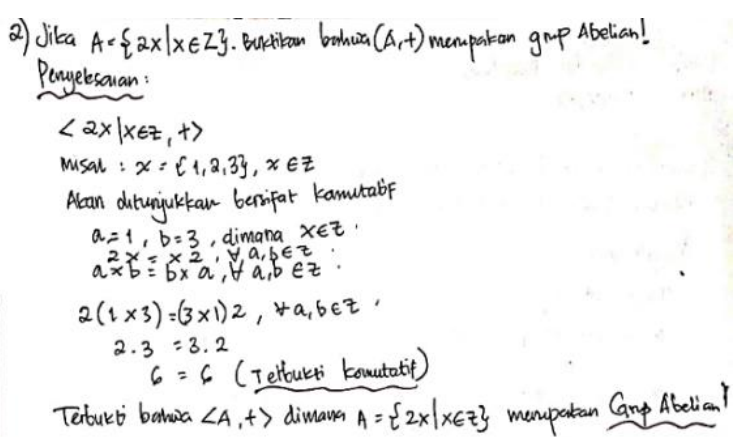

Gambar 5. Lembar Jawaban 2 B

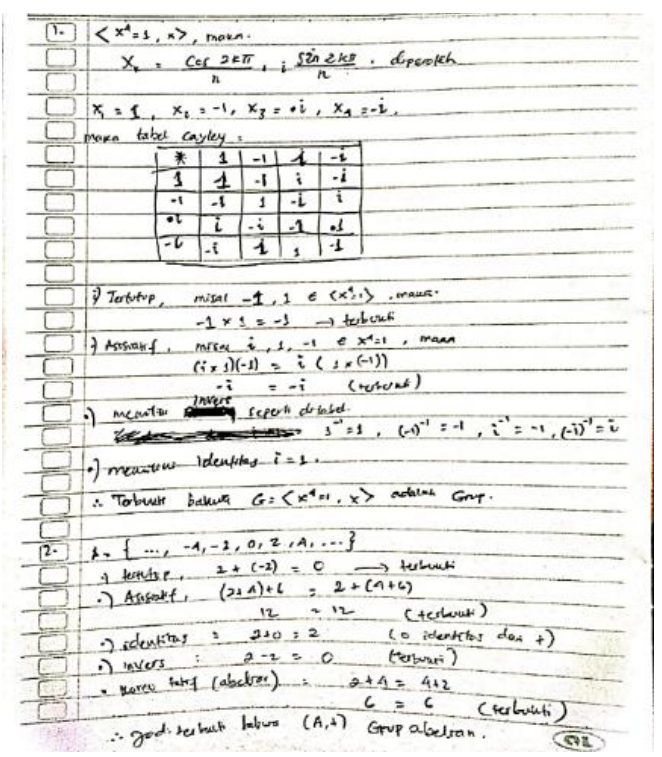

Gambar 6. Lembar Jawaban 1 C

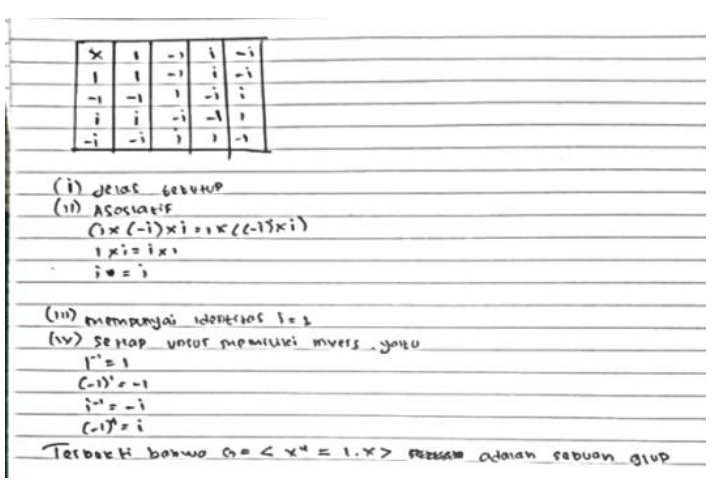

Gambar 7. Lembar Jawaban 1 D

Setelah melakukan tes kepada mahasiswa, peneliti melakukan wawancara dan memperoleh hasil sebagai berikut.

Hasil tes wawancara dengan komponen pertama dapat dilihat pada tabel 2.

Tabel 2. Hasil Wawancara 1

\begin{tabular}{cl}
\hline Subjek & \multicolumn{2}{c}{ Hasil } \\
\hline A & $\begin{array}{l}\text { Subjek pertama dapat menjawab dan } \\
\text { menjelaskan dengan baik mengenai } \\
\text { konsep dan defenisi grup dalam struktur } \\
\text { aljabar grup secara formal dan }\end{array}$ \\
& $\begin{array}{l}\text { terperinci, kemudian juga dapat } \\
\text { menjelaskan suatu grup abelian. }\end{array}$ \\
\hline B & $\begin{array}{l}\text { Subjek kedua menyebutkan bahwa } \\
\text { Grup adalah suatu himpunan beserta }\end{array}$ \\
& $\begin{array}{l}\text { satu operasi biner, seperti perkalian atau } \\
\text { penjumlahan, yang memenuhi beberapa } \\
\text { aksioma }\end{array}$ \\
\hline C & $\begin{array}{l}\text { Subjek ketiga menyatakan bahwa grup } \\
\text { adalah sistem aljabar dengan satu } \\
\text { operasi biner yang memenuhi sifat-sifat } \\
\text { tertentu }\end{array}$ \\
\hline D & $\begin{array}{l}\text { Subjek keempat kurang tepat dalam } \\
\text { menjelaskan defenisi grup }\end{array}$ \\
\hline
\end{tabular}

Hasil tes wawancara dengan komponen kedua dapat dilihat pada tabel 3. 
Tabel 3. Hasil Wawancara 2

\begin{tabular}{cl}
\hline Subjek & Hasil \\
\hline A & Subjek pertama menjelaskan bahwa sebuah Grup G dengan operasi biner * dituliskan dengan simbol < \\
& $G, *>$ jika memenuhi aksioma-aksioma berikut ini : \\
& (i) $\quad a * b=c \in G, \forall a, b \in \mathrm{G}$ \\
& (ii) $\quad a *(b * c)=(a * b) * c, \forall a, b, c \in G$ \\
& (iii) $\quad \exists e \in G \ni e * a=a * e=a \in G$ \\
& (iv) $\forall a \in G, \exists a-1 \in G \ni a * a-1=a-1 * a=\mathrm{e}$ \\
& Atau dapat dikatakan bahwa sebuah grup akan terbukti jika dia dapat dibuktikan tertutup, asosiatif, \\
& memiliki unsur identitas, dan terdapat invers. \\
& Kemudian akan dikatakan grup abelian, jika sebuah grup dapat dinyatakan ataupun dibuktikan dalam \\
& bentuk komutatif, dimana axb akan sama dengan bxa atau a*b = b*a untuk setiap bilangan bulat. \\
\hline B & Subjek kedua kurang lengkap dalam menjelaskan karakteristik sebuah grup dan grup akan dikatakan \\
& abelian, subjek kedua hanya menyebutkan bahwa sebuah Grup $G$ disebut Grup Abelian atau Komutatif jika \\
& berlaku $a * b=b * a \forall a, b \in G$. \\
\hline C & Sama hal nya dengan subjek kedua, subjek ketiga menyebutkan bahwa sebuah grup dinyatakan abelian jika \\
& di dalamnya berlaku sifat komutatif. \\
\hline D & Subjek keempat menyatakan bahwa karakteristik grup adalah jika dapat dibuktikan dan komutatif. \\
\hline
\end{tabular}

\section{Hasil tes wawancara dengan komponen}

ketiga dapat dilihat pada tabel 4 .

Table 4. Hasil Wawancara 3

\begin{tabular}{cl}
\hline Subjek & \multicolumn{1}{c}{ Hasil } \\
\hline A & $\begin{array}{l}\text { Subjek pertama memberikan contoh bahwa himpunan bilangan bulat dengan operasi penjumlahan adalah } \\
\text { grup, sedangkan himpunan bilangan bulat dengan operasi perkalian bukanlah grup. }\end{array}$ \\
& $\begin{array}{l}\text { Hal ini dikarenakan untuk setiap operasi penjumlahan bilangan bulat, maka hasilnya bilangan bulat, dan ini } \\
\text { dapat dibuktikan bahwa bilangan bulat dengan operasi penjumlahan bersifat tertutup. Kemudian dapat } \\
\text { dibuktikan juga asosiatif, terdapat identitas penjumlahan dan juga mempunyai invers. }\end{array}$ \\
& $\begin{array}{l}\text { Sedangkan, bilangan bulat dengan operasi perkalian tidak dapat dikatakan sebagai grup dikarenakan tidak } \\
\text { memiliki invers, hal ini dapat dibuktikan bahwa jika a adalah sebuah bilangan bulat, maka invers perkalian }\end{array}$ \\
& $\begin{array}{l}\text { dari a adalah a }{ }^{-1} \text { atau } \frac{1}{a} \text {, sedangkan } \frac{1}{a} \text { adalah bilangan pecahan, dan pecahan bukanlah anggota dari himpunan } \\
\text { bilangan bulat }\end{array}$ \\
\hline B & $\begin{array}{l}\text { Subjek kedua memberikan contoh }<U 8, x>\text { merupakan sebuah Grup karena memenuhi semua syarat grup. } \\
\text { Contoh bukan grup adalah Himpunan bilangan asli }(\mathrm{N}) \text { tidak bersifat tertutup terhadap operasi pengurangan. }\end{array}$ \\
\hline C & Subjek ketiga memberikan contoh $\langle$ Z, $+>$ adalah sebuah grup \\
\hline D & $\begin{array}{l}\text { Subjek keempat kurang tepat dalam memberikan contoh, subjek keempat menyatakan bahwa himpunan } \\
\text { bilangan asli bukanlah grup }\end{array}$ \\
\hline &
\end{tabular}

Berdasarkan hasil penelitian yang

diambil dari mahasiswa dengan

kemampuan matematis yang berbeda,

didapat bahwa mahasiswa yang memiliki

tingkat matematis yang tinggi akan

memenuhi indikator pemahaman konseptual yang baik, begitu pula sebaliknya dengan mahasiswa yang tidak memiliki pemahaman matematis yang 
tinggi tidak akan memenuhi indikator pemahaman konseptual yang baik.

Sehingga, jika penelitian diukur dengan hasil rata-rata indikator setiap mahasiswa, maka dapat dikatakan bahwa tingkat pemahaman konseptual mahasiswa terhadap materi grup berada pada tingkat sedang atau menengah.

Hal ini dapat dilihat dari hasil yang diperoleh oleh keempat subjek penelitian, dimana subjek pertama dapat menyelesaikan soal dengan baik dan benar, serta dapat menjawab dan menjelaskan setiap pertanyaan yang ada sehingga jika dinilai dari segi matematis dan pemahaman subjek pertama memiliki kemampuan matematis tinggi. Sedangkan subjek kedua dan ketiga masih terdapat indikator yang belum terpenuhi dalam penelitian kali ini dimana masih terdapat kekeliruan dalam menjawab pertanyaan yang telah diberikan sehingga dapat dinilai bahwa subjek kedua dan ketiga memiliki kemampuan matematis sedang. Sedangkan subjek keempat terdapat banyak kekeliruan dalam menjawab pertanyaan, dan subjek keempat dianggap kurang mampu dalam memenuhi indikator pemahaman konseptual sehingga subjek keempat dinilai memiliki kemampuan matematis yang rendah.

Hal tersebut sejalan dengan hasil penelitian yang telah dilakukan Listiawati (2015) yang menyatakan bahwa mahasiswa dengan kemampuan matematis yang tinggi akan memiliki pemahaman konseptual yang baik, sedangkan mahasiswa dengan kemampuan matematis sedang dianggap masih belum sepenuhnya menguasai beberapa konsep dalam materi grup. Sedangkan hasil penelitian yang dilakukan oleh Faizah (2019) didapat bahwa mahasiswa dengan kemampuan matematis yang tinggi dapat menguasai indikator pemahaman konsep yang baik, sedangkan kemampuan matematis yang rendah dianggap masih mengalami kekurangan dalam memahami konsep, dan kemampuan matematis yang rendah masih kurang baik dalam memahami dan menguasai konsep grup.

\section{Kesimpulan}

Berdasarkan hasil penelitian tentang pemahaman konseptual mahasiswa terhadap materi grup yang dilakukan di Universitas Islam Negeri Sumatera Utara Medan dengan subjek penelitian mahasiswa pendidikan matematika semester 5 yang telah mempelajari materi grup diperoleh hasil bahwa tingkat pemahaman rata-rata yang diukur dari indikator pemahaman konseptual berada pada tingkat menengah atau sedang. Hal ini didapat dari hasil tes yang dilakukan kepada mahasiswa dengan tingkat matematis yang berbeda, dan 
diperoleh hasil bahwa mahasiswa dengan kemampuan matematis yang tinggi akan memperoleh hasil indikator pemahaman konseptual yang baik mengenai teori grup pada struktur aljabar, sedangkan mahasiswa dengan kemampuan matematis yang sedang belum sepenuhnya menguasai teori grup dikarenakan masih terdapat kekurangan dalam hasil indikator pemahaman konseptual terhadap materi grup, dan mahasiswa dengan tingkat matematis yang rendah memiliki pemahaman konseptual yang kurang terhadap materi grup dalam struktur aljabar grup.

Sehingga disarankan kepada dosen agar lebih menekankan materi grup kepada mahasiswa yang diajar, saran untuk mahasiswa agar lebih memperdalam pemahaman tentang grup pada perkuliahan struktur aljabar grup sebelum lanjut ke permasalahan yang lebih kompleks. Disarankan juga untuk penelitian selanjutnya yaitu perlu dikaji lebih mendalam mengenai presentase pemahaman konseptual mahasiswa terhadap materi grup pada perkuliahan struktur aljabar dengan memperbanyak tes dan subjek penelitian agar hasil yang diperoleh lebih akurat.

\section{Ucapan Terimakasih}

Peneliti mengucapkan terimakasih kepada mahasiswa Pendidikan
Matematika semester V UIN SU Medan yang telah bersedia menjadi sampel dalam penelitian. Peneliti juga berterimakasih kepada seluruh pihak yang ikut serta membantu secara langsung maupun tidak secara langsung dalam penelitian kali ini, sehingga penulisan ini dapat tersusun dengan sebaik mungkin.

\section{Pustaka}

Amalia, S. R., \& Widodo, A. N. A. (2018). Analisis Kemampuan Pemecahan Masalah Mahasiswa Melalui Model Pbl Berbasis Etnomatematika Ditinjau Dari Kepribadian Topologi Hippocrates Dan Galenus Tipe Cholearis Dan Phlegmantis. Aksioma: Jurnal Matematika Dan Pendidikan Matematika, 9(1), 1-10. https://doi.org/10.26877/aks.v9i1. 2467

Ambarwati, M. (2016). Analisis Kemampuan Pemecahan Masalah dalam Strategi Think Talk Write (TTW). Pedagogia: Jurnal Pendidikan, 5(2), 239-246. https://doi.org/10.21070/pedagogi a.v5i2.256

Amir, A. (2015). Pemahaman Konsep Dan Pemecahan Masalah Dalam Pembelajaran Matematika. Logaritma: Jurnal Ilmu-Ilmu Kependidikan Dan Sains, 3(1).

Darma, Y., Firdaus, M., \& Haryadi, H. (2016). Hubungan Kemandirian Belajar Terhadap Kemampuan Pemecahan Masalah Matematis Mahasiswa Calon Guru Matematika. Jurnal Edukasi, 14, 169-178. 
Darminto, B. P. (2009). Upaya Peningkatan Pemahaman Konsep Aljabar dan Sikap Mahasiswa Calon Guru Matematika terhadap Pembelajaran Berbasis Komputer. Makalah Dipresentasikan Dalam Seminar Nasional Aljabar, Pengajaran Dan Terapannya. Jurusan Pendidikan Matematika FMIPA UNY Yogyakarta. Dapat Diakses Online Pada:

Https://Eprints.Uny.Ac.Id/7426/.

Darminto, B. P. (2013). Meningkatkan Kemampuan Pemecahan Masalah Matematis Mahasiswa Melalui Pembelajaran Model Treffinger. Jurnal Pendidikan Matematika Dan Sains, 1(2), 101-107. https://doi.org/10.21831/jpms.v2i 2.2476

Fadillah, S., \& Jamilah. (2016). Developing Algebraic Structure Teaching Materials To Improve Students' Mathematical Proof Ability. Cakrawala Pendidikan, XXXV(1), 106-113.

Faizah, H. (2019). Profil Pemahaman Konseptual Mahasiswa Calon Guru Matematika tentang Grup Ditinjau dari Kemampuan Matematika. Jurnal Didaktik Matematika, 6(2), 84-97. https://doi.org/10.24815/jdm.v\%v i\%i.13914

Fitria, A. (2014). Miskonsepsi Mahasiswa Dalam Menentukan Grup Pada Struktur Aljabar Menggunakan Certainty Of Response Index (Cri) Di Jurusan Pendidikan Matematika Iain Antasari. Jpm Iain Antasari, 1(2), 45-60.

Haji, S. (2014). Meningkatkan kemampuan pemahaman konsep melalui pembelajaran matematika concept-rich. Makalah Disajikan Dalam Seminar Pendidikan Matematika Program Studi Pascasarjana (S2) Pendidikan Matematika Fakultas Keguruan Dan Ilmu Pendidikan Universitas Bengkulu 2014. Dapat Diakses Online Pada: Http://Repository.Unib.Ac.Id/718 81.

Hamalik, O. (2000). Kurikulum dan Pembelajaran. Jakarta: Bumi Aksara.

Hayu, E., Linna, R., Maimunah, \& Roza, Y. (2019). Analisis Kemampuan Koneksi Matematis Siswa Dalam Menyelesaikan Masalah Pada Materi Perbandingan. AdMathEdu: Jurnal Ilmiah Pendidikan Matematika, Ilmu Matematika Dan Matematika Terapan, 9(1), 11-20.

Listiawati, E. (2015). Pemahaman Mahasiswa Calon Guru Pada Konsep Grup. Jurnal APOTEMA, 1(2), 76-86.

Maysarah, S. (2017). Peningkatan Kemampuan Berpikir Kreatif Matematik Siswa Melalui Model Project Based Learning Berbantuan Ms. Excel Di Kelas Xi Sma Asy-Syafi'iyah Internasional Medan. Axiom: Jurnal Pendidikan Dan Matematika, 6(2), 25-35.

Nila, K. (2008). Pemahaman konsep matematik dalam pembelajaran matematika. Prosiding Seminar Nasional Matematika Dan Pendidikan Matematika, Jurusan Pendidikan Matematika Fakultas Matematika Dan Ilmu Pengetahuan Alam Universitas Negeri Yogyakarta. 
Rubowo, M. R., Purwosetiyono, FX. D., \& Wulandari, D. (2017). Pemahaman Konsep Mahasiswa Tentang Ring Pada Mata Kuliah Struktur Aljabar 2 Ditinjau Dari Pemikiran Kreatif Pada Siswa Kelompok Atas. Jurnal Silogisme, 2(2), 69-73. http://journal.umpo.ac.id/index.ph $\mathrm{p} / \mathrm{silogisme}$

Ruseffendi, E. T. (2006). Pengantar Kepada Membantu Guru Mengembangkan Kompetensinya Dalam Pengajaran Matematika Untuk Meningkatkan CBSA: Perkembangan kompetensi guru. Bandung: Tarsito. 